\title{
Seismic Performance Evaluation of Existing Building in Earthquake Prone Area Based on Seismic Index and Seismic Demand Method
}

\author{
Rusnardi Rahmat Putra ${ }^{1,2, *}$, Yusuke Ono ${ }^{3}$, Nurhasan Syah $^{1}$, A. A. Cantika ${ }^{1}$ \\ ${ }^{1}$ Department of Civil Engineering, Faculty of Engineering, Universitas Negeri Padang, Indonesia \\ ${ }^{2}$ Research Centre for Disaster, Universitas Negeri Padang, Indonesia \\ ${ }^{3}$ Faculty of Engineering, Social Systems and Civil Engineering, Tottori University, Japan
}

Received March 30, 2021; Revised May 19, 2021; Accepted June 15, 2021

\section{Cite This Paper in the following Citation Styles}

(a): [1] Rusnardi Rahmat Putra, Yusuke Ono, Nurhasan Syah, A. A. Cantika, "Seismic Performance Evaluation of Existing Building in Earthquake Prone Area Based on Seismic Index and Seismic Demand Method," Civil Engineering and Architecture, Vol. 9, No. 4, pp. 1237-1245, 2021. DOI: 10.13189/cea.2021.090425.

(b): Rusnardi Rahmat Putra, Yusuke Ono, Nurhasan Syah, A. A. Cantika (2021). Seismic Performance Evaluation of Existing Building in Earthquake Prone Area Based on Seismic Index and Seismic Demand Method. Civil Engineering and Architecture, 9(4), 1237-1245. DOI: 10.13189/cea.2021.090425.

Copyright $\bigcirc 2021$ by authors, all rights reserved. Authors agree that this article remains permanently open access under the terms of the Creative Commons Attribution License 4.0 International License

\begin{abstract}
Padang is the capital of West Sumatra Province, close to three earthquake sources such as the Megathrust Zone, the Mentawai Fault, and the Great Sumatra Fault on the mainland. Due to the fact that the impact of the earthquake can create a tsunami event in the future, the government needs to prepare shelters for vertical evacuation. About 65 existing buildings have been selected as vertical evacuation buildings, but there is no clear information on their seismic performance. This research proposes a complete assessment of the existing $\mathrm{RC}$ building by considering soil characteristics such as the predominant period and Vs30 from microtremor observations. A selected 3 stories of a school building located in the earthquake red zone (Vs30<150m/s and predominant period $\mathrm{T}>1.5 \mathrm{~s}$ ), less than $1 \mathrm{Km}$ far from the shoreline, was considered in this paper. Based on the seismic index evaluation of the building, the $\mathrm{X}$ direction is smaller than the seismic demand (0.8) for the first and second floors (unsatisfactory). For the first, second and third floor, the $\mathrm{Y}$ direction has a larger seismic index than the seismic demand. Therefore, the performance is satisfactory for the first to the third story. Based on the required inspection, the building is unsatisfactory for the $\mathrm{X}$-direction. Therefore, it needs to be strengthened. We propose a re-size of the RC for the building column to
\end{abstract}

improve the ductility. The proposed size for the column is $50 \times 60 \mathrm{~cm}$. From the re-seismic evaluation, a satisfactory seismic index for the $\mathrm{X}$ and $\mathrm{Y}$ direction can be obtained.

Keywords Seismic Index, Seismic Demand, Seismic Performance, Seismic Evaluation

\section{Introduction}

Indonesia is a country that is crossed by a world ring of fire that has the potential for earthquakes and tsunamis. Indo-Australian plate movement in Western Indonesia is $7 \mathrm{~mm} /$ year, and the Pacific plate movement in Eastern Indonesia is $12 \mathrm{~mm} /$ year [1]. The magnitude of this movement indicates that each plate is actively moving with the number of earthquakes occurring annually, which is 1200 times with an intensity $>4$ on the Richter scale [2]. Figure 1 shows that more than 60,000 earthquakes occurred in Indonesia from 1779-2020 with a strength > Mw4. Most earthquakes that occur in Indonesia are shallow earthquakes that have the potential to produce a large acceleration in surface soil. 


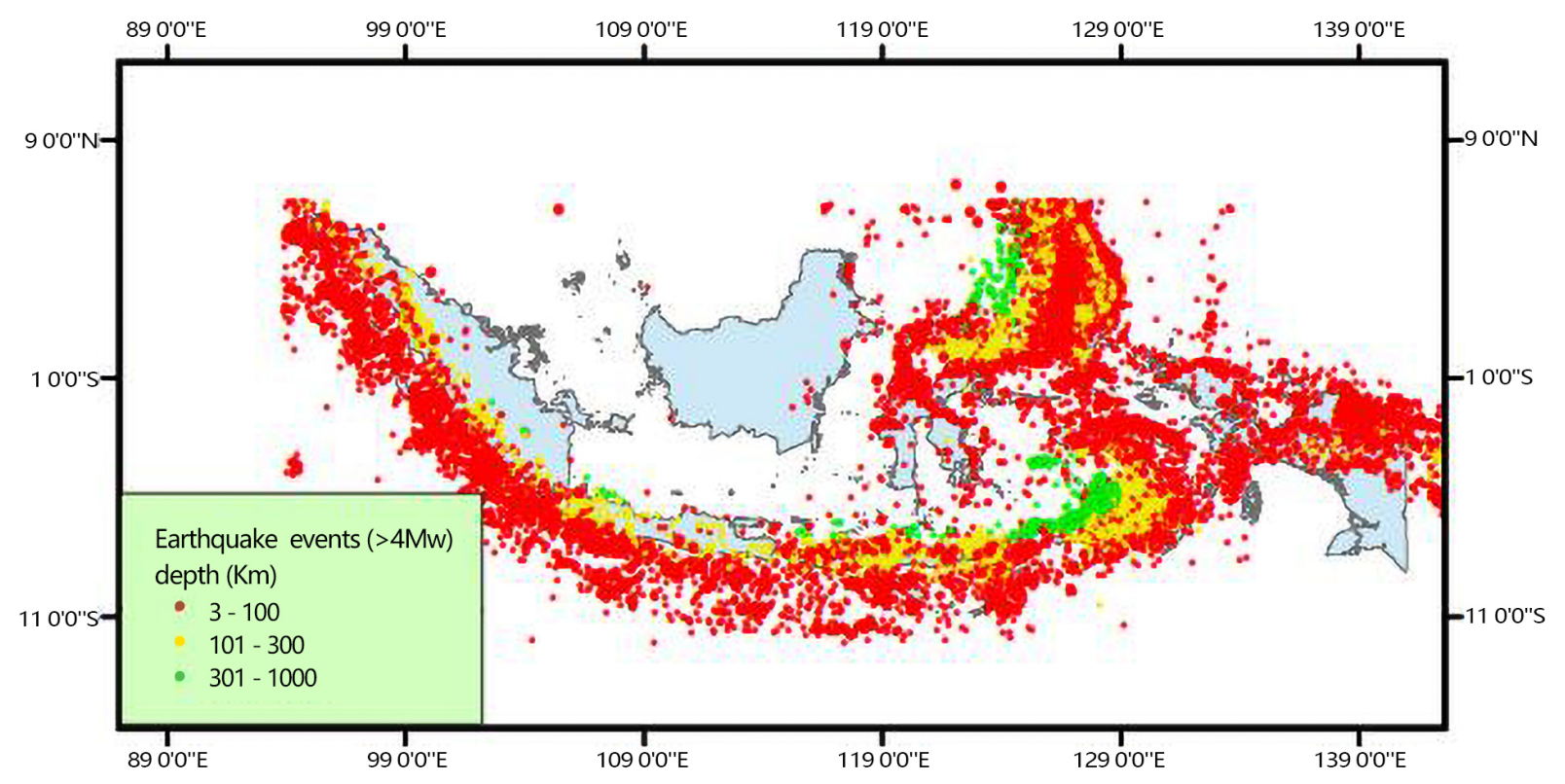

Figure 1. Seismicity of Indonesia from 1779-2020 with magnitude $>4$ [3].

West Sumatra is one of the provinces located in the western part of Indonesia. Geographically, the province of West Sumatra has three sources of earthquakes which have the potential to cause large scale earthquakes [4-5]. If the earthquake occurs at subduction $200 \mathrm{~km}$ far from the land, it can cause a tsunami [6-8]. The land on West Sumatra island is on a known fault line that crosses from Singkarak, Padang Panjang, Padang, and Painan along $500 \mathrm{Km}$. Earthquake data from 1779-2019 shows the characteristics of the earthquake that occurred was a large magnitude earthquake because this earthquake was shallow as in 1928 (Mw8.4), 1933 (Mw9.3), 1981 (Mw8.1) and 2007 (Mw8. 4)[9] and its seismic condition are similar with Palu city which struct which by earthquake and tsunami in 2018[10].

\subsection{Regional Geology and Recent Earthquakes}

Padang city is located on the west coast of the island of Sumatra in western Indonesia, situated close to the Sumatran subduction zone and on the fault line formed on the Indo-Australian plate.

Padang city, with a population of 927.168 people as of 2017, is the capital of West Sumatra province [11]. The location of the downtown is at $100.38^{\circ} \mathrm{E}, 0.95^{\circ} \mathrm{S}$.

One of the major earthquakes that occurred in the last ten years is the one on 30 September 2009. It had a magnitude of 7.9 on the Richter scale and occurred at a depth of $71 \mathrm{~km}$ southwest of the city of Padang. This earthquake caused 1117 victims to die, two of them missing, and 1214 others seriously injured [12]. The earthquake occurred at 17:16 WIB, and it was also felt in Gunung Sitoli, Mukouko, Sibolga, Liwa, Padang, Jakarta, Singapore, and Malaysia [13,14]. It might have caused more victims if it had occurred during office hours or school hours. The earthquake also damaged infrastructure in the city including hospital facilities and water installations from the Regional.

Water Utilities (PDAM). Water Utilities (PDAM) did not operate for more than ten working days, making it difficult for the public to access clean water. Besides, the earthquake almost destroyed the entire existing infrastructure in the city of Padang, which harmed the economy. West Sumatra, which is where the city of Padang is located, also has the potential of a tsunami because it has a source of earthquakes in the sea (subduction) where the Indo-Australian plate pushes the stable Indonesian plate. A force that exceeds the plate elasticity will generate a large tsunami, as in 1833 (Mw9.2), 2005 (Mw9.3), and the last one in 2010 which occurred in Mentawai. Lately, there have been earthquakes in the region predicted as a megathrust segment of more than 61 earthquake events with strength above $4 \mathrm{Mw}$. This incident could have triggered a large earthquake in this subduction area. Figure 2 shows the tsunami events from1600-2020. 


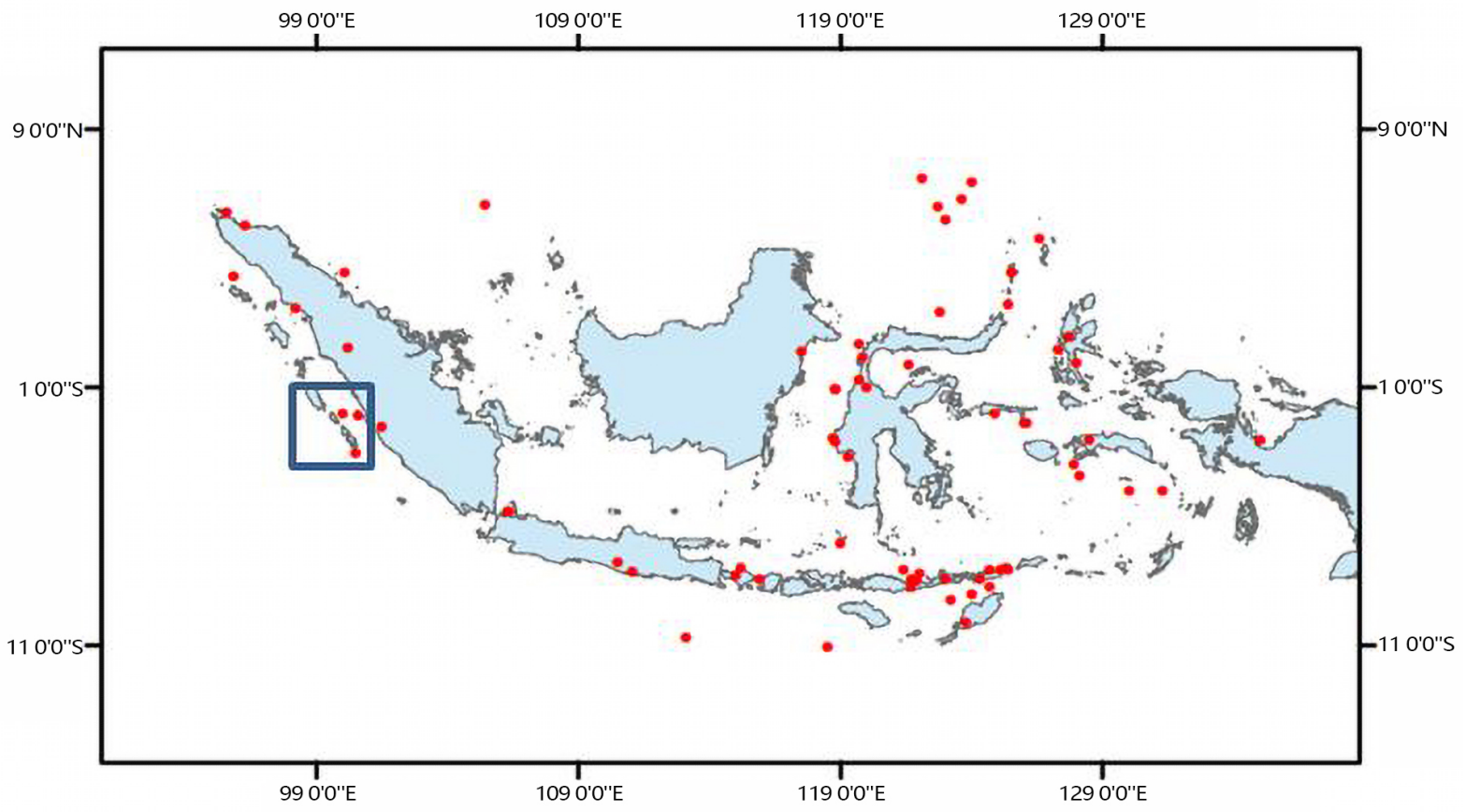

Figure 2. The tsunami history of Indonesia from 1600-2020, the blue box is the location of the tsunami that affected Padang city [14].

Since the city site is less than $3 \mathrm{Km}$ from the west coast of Sumatra, has a high density of population and potential for earthquake-tsunami to occur in future, the city government is preparing the mitigation to face the upcoming earthquake by arranging an evacuation site. There are about 65 buildings distributed over $100 \mathrm{Km}^{2}$ of downtown which are designed as earthquake and tsunami shelters. These shelters are expected to function properly, both in terms of structural strength and altitude, which are higher than the tsunami height inundation $[15,16]$. The tsunami inundation probability is worsened by the topographic condition of the city of Padang. Some parts of the city centre, located close to the coast, have a lower elevation than the sea level (less than $3 \mathrm{~m}$ ). Besides, the community evacuation by using vehicles makes it difficult for them to reach safe areas. It is necessary to evacuate the people to a higher place so that people living around the West coast of Sumatra can do self-evacuation faster and safer.

The last earthquake of September 30, 2009, showed that most buildings constructed before the year 2009, by following the seismic-resistant building code of 2002, had an acceleration of response spectrum at $0.2-0.8 \mathrm{~s}$, lower than the acceleration of September 30, 2009 (Fig.4). This is the main reason to make sure the seismic performance of the designed vertical evacuation, the vertical evacuation is evacuating to a high floor of a building, instead of leaving the tsunami evacuation zone.

\subsection{Site Characterization by Microtremor Observation}

The location of the tested building is near the coastal area, less than $1 \mathrm{Km}$ from the shore. We conducted microtremor single observations for 140 sites and microtremor arrays for 12 sites, by analysing the Rayleigh wave records data from each survey such as $\mathrm{H} / \mathrm{V}$ ratio [17-20], soil profile applied SPAC method [21], and in the inversion analysis, the Particle Swarm Optimisation (PSO) [22]. From the obtained results, the soil characteristic is soft soil where the predominant period is more than one second, and the $\mathrm{Vs}_{30}$ (as the average seismic shear-wave velocity from the surface to a depth of 30 meters) is less than $150 \mathrm{~m} / \mathrm{s}$ (Figs. 3 (a) and (b)) [11]. As shown in Figure 4, in the short period range, the elastic design spectra for the 2002 code are comparable to the spectral accelerations of the measured ground motions. Whereas the values for the 1970 code and 2002 are smaller compared spectral acceleration of the measured ground motions, the elastic design spectra are shown in Figure 4 (red, blue and green) are of soft sites in downtown Padang. Comparison of response spectra in each standard; the red line is the current spectra of Padang earthquake 2009. 


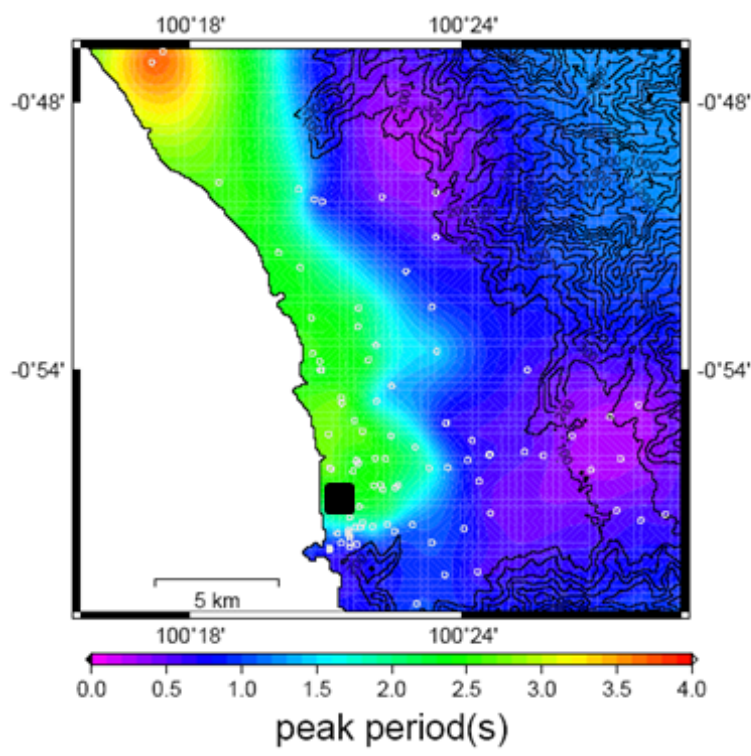

(a)

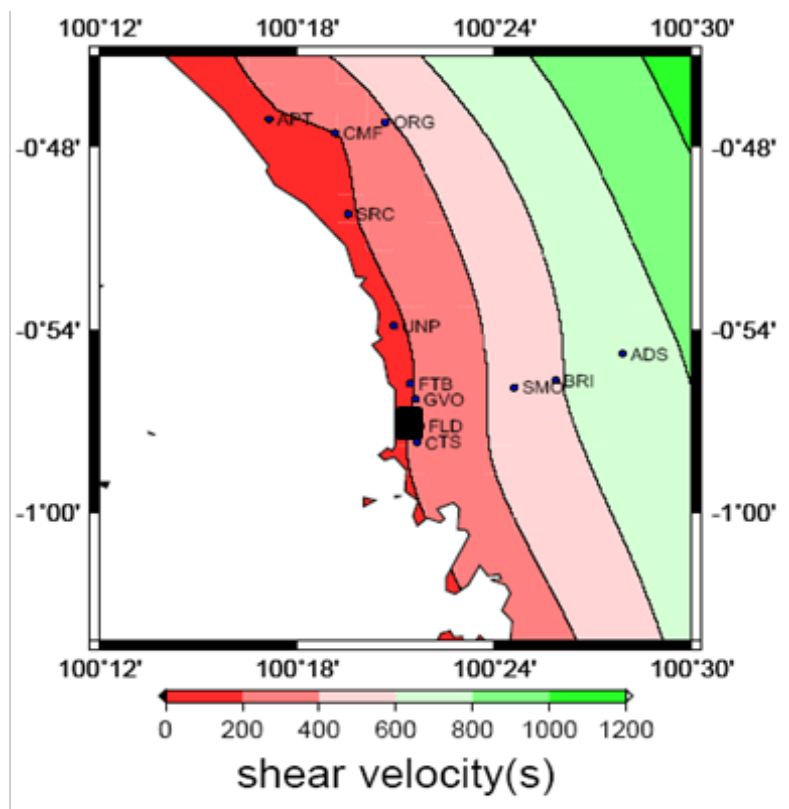

(b)

Figure 3. Building target location (a) H/V ratio for whole Padang city, (b) Vs30 for whole Padang city [10]

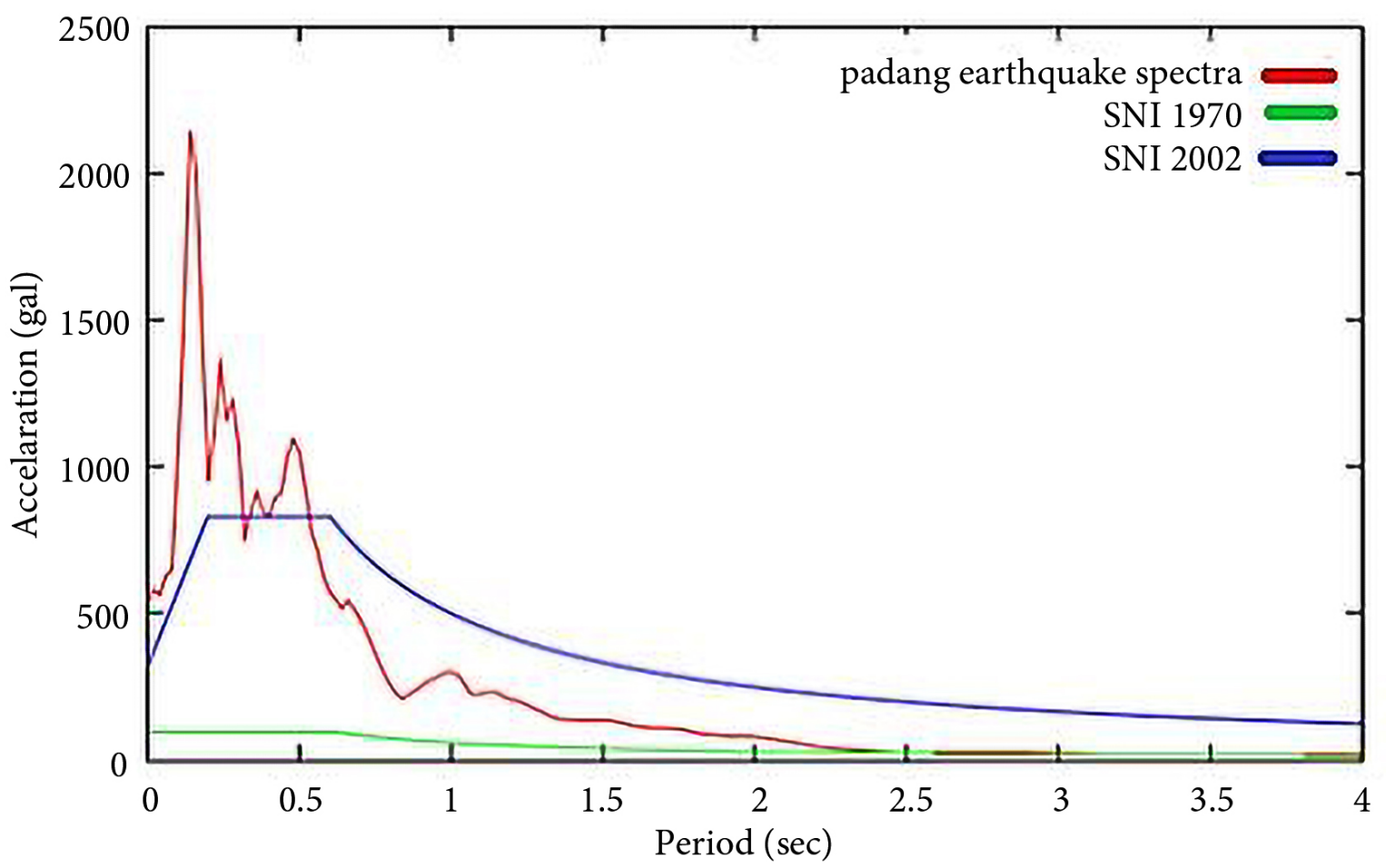

Figure 4. Comparison of the existing standard spectrum response with the 2009 earthquake [2] 


\section{Methodology of Research}

To determine the performance of a building, it must include a non-structural part. The selected building will be assessed for the first screening by following the procedure of the standard for Seismic Evaluation of Existing Reinforced Concrete Building, 2001 [23] (Fig 5). Some aspects need to be considered in this study, such as;

a. The details that we need to focus on in the first level screening which include floor plan, aspect ratio, regularity, expansion joint, narrow part, well-styled hall, size, and location.

b. Items related to section plan of the basement, uniformity of the height, the existence of pilots.

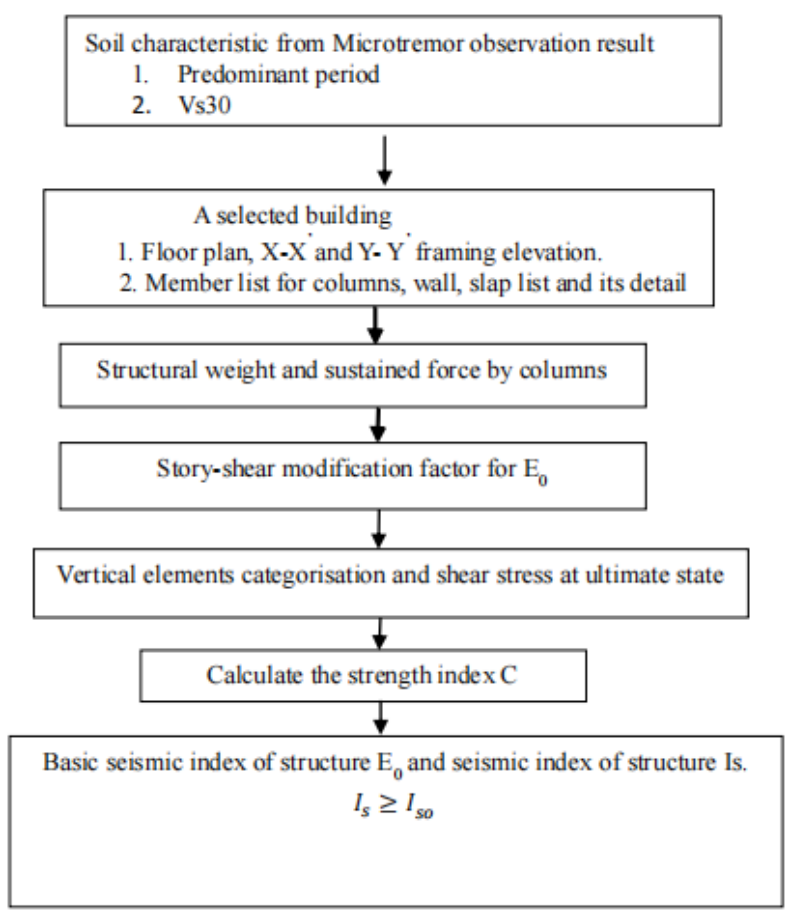

Figure 5. The assessment and calculation procedures

\subsection{Seismic Index $\left(I_{S}\right)$}

The seismic index is an index representing the seismic performance of structures based on their strength and ductility [16]. This research applied a standard for seismic evaluation of existing reinforced Concrete Building, 2001 from the Japan Building Disaster Prevention Association. The seismic index is calculated based on Eq. 1 for each story, and in each principal horizontal direction of the building.

$$
I_{S}=E_{O} \times S_{D} \times T
$$

Where $I_{S}$ is the Basic seismic index of a building representing the seismic performance of a structure, $E_{O}$ represents the basic seismic performance of a building by assuming other sub-indices as unity, it is calculated for each story and each direction based on ultimate strength, failure mode and ductility, and $S_{D}$ is the Irregularity index that modifies the basic seismic index of the structure in stiffness distribution and irregularities in the structure plan, and each elevation of a building. $T$ is the time index that modifies the basic seismic of the structure. It is significant since we also consider that the building is ageing.

Basic seismic index $\boldsymbol{I}_{\boldsymbol{S}}$ and structure $E_{O}$ shall be taken as the larger values from equations (2) and (3), equation 3 is only in case the story consists of extremely short columns.

$$
\begin{gathered}
E_{O}=\frac{n+1}{n+1}\left(C_{W}+\alpha C_{C}\right) F_{W} \\
E_{O}=\frac{n+1}{n+1}\left(C_{s C}+\alpha_{2} C_{w}+\alpha_{3} C_{C}\right) F_{s C}
\end{gathered}
$$

Where $n$ is the number of the story of a building, $C_{W}$ is the strength index of the wall, $C_{C}$ is the strength index of the column, $\alpha$ is the effective strength factor, and $F_{W}$ is the ductility index of the wall (ductility index of the column in case nearly equal to 0 , which may be taken as 1.0 , in table 1).

$$
\begin{gathered}
C_{w}=\frac{\sigma_{w 1 .} A_{w 1}+\sigma_{w 2 .} A_{w 2}+\sigma_{w 3 .} A_{w 3}}{\sum W} \times \beta_{c} \\
C_{C}=\frac{\tau_{C} x A_{C}}{\sum W} \times \beta_{c} \\
C_{S C}=\frac{\tau_{S C} \times A_{S C}}{\sum W} \times \beta_{c} \\
\beta_{c}=\frac{F_{C}}{20} \leq 20 \\
\beta_{c}=\sqrt{\frac{F_{c}}{20}} \leq 20
\end{gathered}
$$

Where the $C_{w}$ is strength index of the walls, $C_{C}$ is the strength index of the columns (equation 5), $C_{s C}$ is the strength index of extremely short columns (equation 6), $\alpha_{1}$ is the effective strength factor of the column at the ultimate deformation of the wall, which may be taken as 0.7 . The value should be 1.0 in the case of $C_{w}=0 . \alpha_{2}$ is the effective strength factor of the walls at the ultimate deformation of extremely short columns, which may be taken as $0.7, \alpha_{3}$ is the effective strength factor of the walls at the ultimate deformation of extremely short columns, which may be taken as $0.5, F_{W}$ is the ductility index of the walls (ductility index of columns in case $C_{w}$ is nearly equal to 0 ) which may be taken as $1.0, F_{S C}$ is the ductility index of extremely short columns, which may be taken as $0.8 . \mathrm{T}_{\mathrm{C}}$ is the average shear stress at the ultimate state of columns, which may be taken as 1 $\mathrm{N} / \mathrm{mm}^{2}$ or $0.7 \mathrm{~N} / \mathrm{mm}^{2}, \mathrm{~A}_{\mathrm{C}}$ is the total cross-sectional area, $\mathrm{W}$ is the weight supported by the story, $\beta_{c}$ is the specified design concrete strength in case without special inspection but should not exceed $20 \mathrm{~N} / \mathrm{mm}^{2}$ ratio and $F_{c}$ is the obtained compression strength of the concrete from the result of the rebound hammer test.

The ductility-dominant basic seismic index of structure for vertical members will be classified by their ductility. The classification is by dividing $\mathrm{F}$ into three or less and defining them as the first, second, and third groups as mentioned in table 1. 
Table 1. Ductility index for $1^{\text {st }}$ screening [24]

\begin{tabular}{|c|c|}
\hline Vertical member & Ductility index $\boldsymbol{F}$ \\
\hline Column $\left(\frac{h_{o}}{D}>2\right)$ & 1.0 \\
\hline Extremely short column & 0.8 \\
$\left(\frac{h_{o}}{D} \leq 2\right)$ & 1.0 \\
\hline Wall & \\
\hline
\end{tabular}

Where the $h_{0}$ is column clear height and $D$ is column depth.

The groups are in order of the smallest to the highest of the indicated ductility value. The $F$ index is one for the first group, and it reduces for the second and the third group. Then the ductility index corresponding to the ultimate deformation of each story is presented in the equation.

$$
S_{D 1}=q_{1 a} \times q_{1 b} \times \ldots \ldots \times q_{1 j}
$$

Where

$$
\begin{gathered}
q_{1 i}=\left[1-\left(1-G_{i}\right) \times R_{1 j}\right] \ldots \ldots i=a, b, c, d, e, f, i, j \\
q_{1 i}=\left[1.2-\left(1-G_{i}\right) \times R_{1 j]}\right] \ldots \ldots \ldots \ldots i=h
\end{gathered}
$$

$q_{1 i}$ is geometric product of degree of incidence, $G_{i}$ is the grade index, $R_{1 j}$ is the range adjustment factor for the screening level and a to $\mathrm{j}$ are objects of the application.

The time index $T$ evaluates the effects of the structural defects such as cracking, deflection, aging, and the like, on the seismic performance of a structure [21].

\subsection{Seismic Demand Index $\left(I_{S o}\right)$}

Seismic demand $\left(I_{S O}\right)$ is the standard level of the seismic index required for a building to be safe during an earthquake when it happens on the site of the building. In equation $8, E_{S}$ is the basic seismic demand index of the structure, standard value of which shall be selected as follows regardless of the direction of the building. The selected standard values are 0.8 for the first level screening. $Z$ is the zone index which depends on the seismic activities in the expected site or region. $G$ is a ground index, namely the modification factor accounting for the effects of the amplification of the surface soil, geological conditions, and soil-and-structure interaction on the expected earthquake motions. $U$ is the usage index of the building. The seismic performance of a structure shall be estimated by comparing the seismic index of structure $\left(\mathrm{I}_{\mathrm{S}}\right)$ and the seismic demand index $\left(\mathrm{I}_{\mathrm{SO}}\right)$. If the building's performance is satisfactory, the building is considered "safe" to endure earthquakes. Otherwise, the building's performance is uncertain towards seismic safety.

$$
\begin{gathered}
I_{S} \geq I_{S O} \\
I_{S 0}=E_{S} \times Z \times G \times U \\
C_{T U} \times S_{D}>E_{S} \times Z \times G \times U \\
E_{O} \times S_{D} \times T>E_{S} \times Z \times G \times U
\end{gathered}
$$

Where $C_{T U}$ is the cumulative strength index at the ultimate deformation of structure or accumulated for the members in a story concerning the drift angle (ductility index). It accounts for the compatibility of the members and is modified by the story-shear modification factor. The zone index $Z$, the ground index $G$, and using index $U$ are assumed as 1 , and $S_{D}$ is assumed as 1.0 for each story in this calculation.

\section{Seismic Assessment Result}

Based on the seismic performance evolution procedures to building and figure 6 shows the building properties (column size $40 \times 40 \mathrm{~cm}$ to whole column in this building), the results show that there are some differences in the seismic index of each story of the building. The seismic index evaluation of building $\mathrm{A}$ for both directions reveals that the $\mathrm{X}$ direction is smaller than the seismic demand $(0.8)$. The obtained seismic demand $(0.8)$ was calculated from equation 12. The seismic index evaluation for the first and second floors of the building is unsatisfactory, and the result is satisfactory for the third floor (Fig. 7 (a)) and table 2. The reasons why both the first and second floors are inadequate is the large column spacing. For the $\mathrm{Y}$ direction, the seismic index is larger than the seismic demand (satisfactory for each story). The seismic index evaluation of building A for both directions reveals that the $\mathrm{X}$ is smaller than the seismic demand (0.8). Hence, to improve the current seismic performance, the ductility needs to be upgraded by re-sizing the column size for the whole column at 1 story from $40 \times 40 \mathrm{~cm}$ to $50 \times 60 \mathrm{~cm}$. The current seismic index is greater than 0.8 (Fig. 7b) and table 3. 


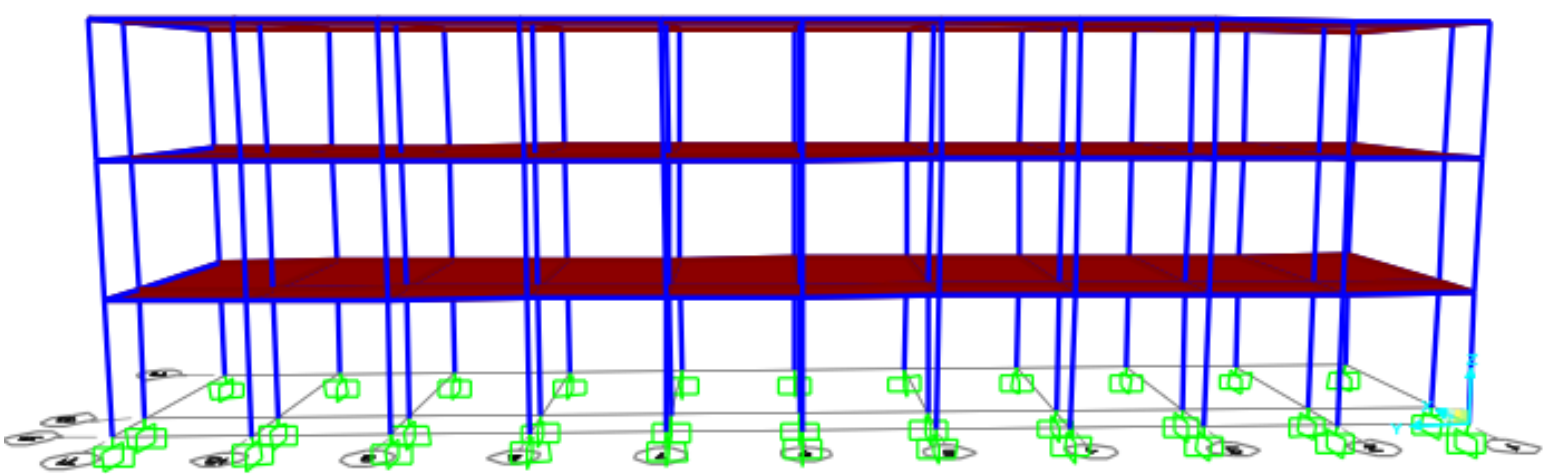

(a)

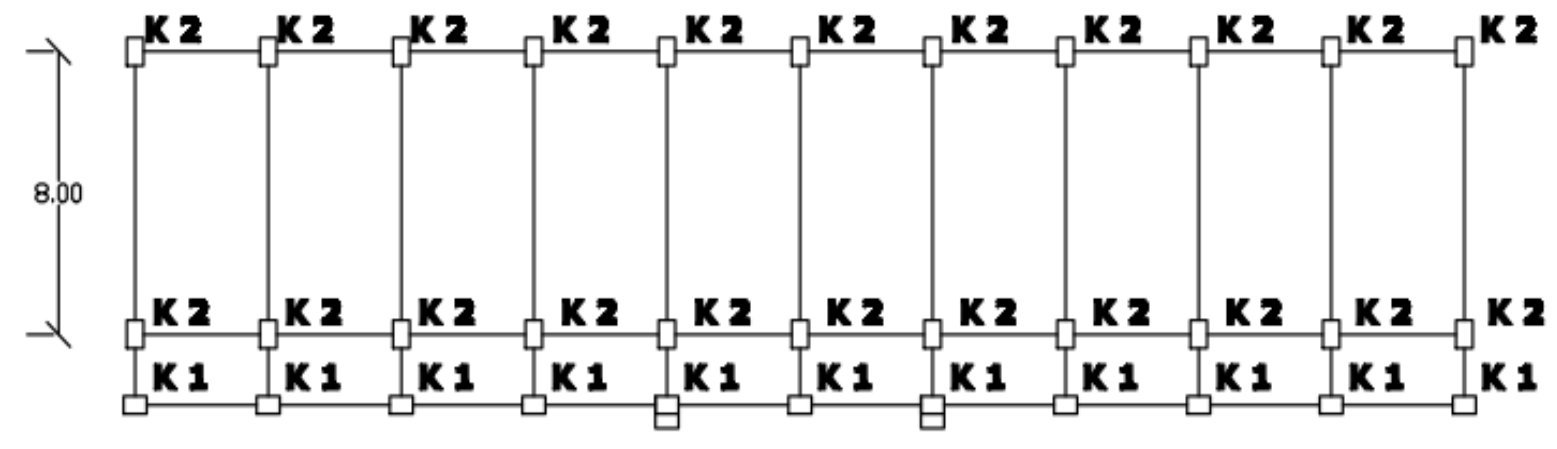

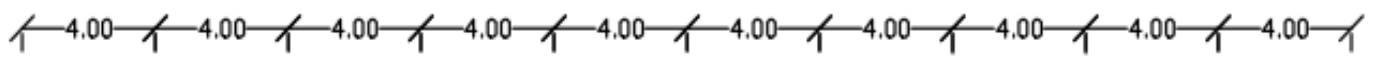

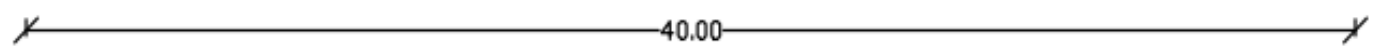

(b)

Figure 6. Building properties (a) 3D front view, (b) site plan

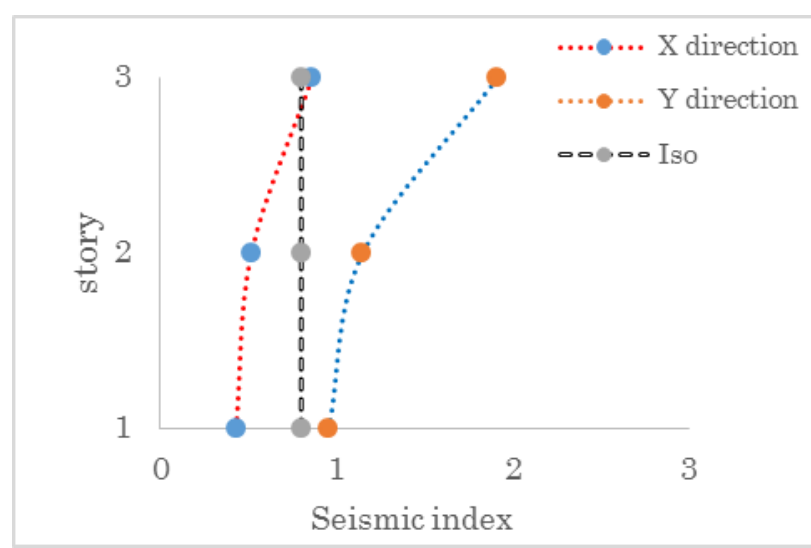

(a)

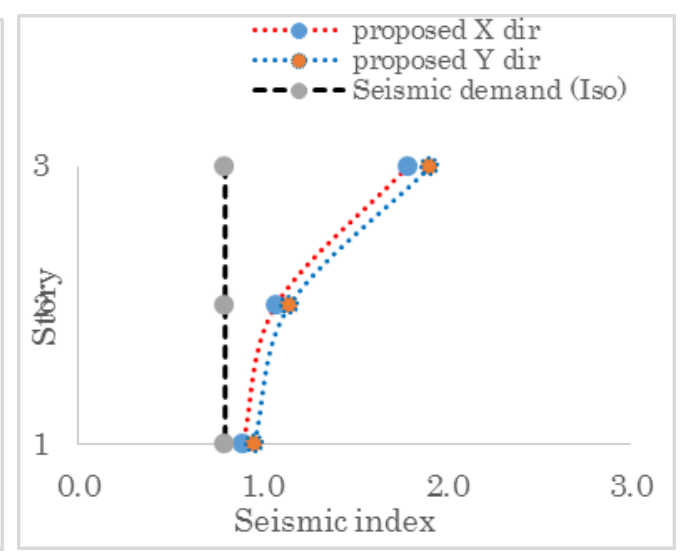

(b)

Figure 7. Seismic index vs seismic demand, (a) Seismic index building (b) Seismic index after retro-fitting 
Table 2. The seismic evaluation result

\begin{tabular}{cccccc}
\hline \multirow{2}{*}{ Direction Story } & Is & Iso & \multicolumn{3}{c}{ Evaluation } \\
& & & & Is $>=$ Iso & Judgment \\
\hline & 3 & 1.5 & 0.8 & safe & satisfactory \\
$\mathrm{Y}$ & 2 & 0.9 & 0.8 & safe & satisfactory \\
& 1 & 0.8 & 0.8 & safe & Satisfactory \\
& 3 & 0.67 & 0.8 & uncertain & Unsatisfactory \\
& 2 & 0.4 & 0.8 & uncertain & Unsatisfactory \\
& 1 & 0.3 & 0.8 & uncertain & unsatisfactory \\
\hline
\end{tabular}

Table 3. The seismic evaluation result after resizing the column size

\begin{tabular}{cccccc}
\hline \multirow{2}{*}{ Direction Story } & Is & Iso & \multicolumn{3}{c}{ Evaluation } \\
& & & & Is $>=$ Iso & Judgment \\
\hline & 3 & 1.9 & 0.8 & safe & satisfactory \\
$\mathrm{Y}$ & 2 & 1.15 & 0.8 & safe & satisfactory \\
& 1 & 0.96 & 0.8 & safe & satisfactory \\
& 3 & 1.8 & 0.8 & safe & satisfactory \\
$\mathrm{X}$ & 2 & 1.1 & 0.8 & safe & satisfactory \\
& 1 & 0.9 & 0.8 & safe & satisfactory \\
\hline
\end{tabular}

\section{Discussion}

The vulnerability assessment of public buildings in earthquake-prone in Spain is a priority [24]. We considered the seismic zone in the calculation to obtain the seismic demand $\left(I_{S}\right)$ of 0.8 where it was adopted from the Japan region because the seismic region in Indonesia is similar to Japan [25,26]. The various seismic performance evolution methods have been conducted in some places in Indonesia [27,28]. In this research the assessment and seismic evolution procedure is the first screening, and the results show that there are some differences in the seismic index of each story of the building. The seismic index evaluation of building A for both directions reveals that the $\mathrm{X}$ is smaller than the seismic demand (0.8). The seismic index evaluation for the first and second floors of the building are unsatisfactory, but it is satisfactory for the third floor. We found the column-to-column distance is too large $(8 \mathrm{~m})$. For demand performance for seismic retrofit, this research considers the RC jacketing method for improving the ductility and strength $[29,30]$. We propose to re-size the existing column size from $40 \times 40 \mathrm{~cm}$ to $50 \times 60 \mathrm{~cm}$. We found the assessment on first screening was fast and easy during assessing, calculating and giving clear a preliminary judgment but not for getting the ductility and strength values. The first screening is suitable for a preliminary judgement and for the next, second and third screenings are necessary.

\section{Conclusions}

Building A is not satisfactory as a future vertical evacuation shelter because the building's seismic index is smaller than seismic demand (0.8). The building needs improvement to enhance the seismic performance. There are several methods to increase seismic performance: upgrading the strength and ductility, reducing the seismic force, and strengthening the foundation. This research aims to improve the seismic performance by upgrading the ductility by RC jacketing. By re-sizing the column to $50 \times 60 \mathrm{~cm}$, the seismic index of each story of the building reaches the satisfactory index since the seismic index is greater than 0.8 .

\section{Acknowledgments}

The author would like to thank the Local Government of Padang City for providing financial support during the assessment in Padang. Especial thanks to my students who gave the best contribution during the assessment and finally thanks to Universitas Negeri Padang for financial support through research funding with schema Penelitian Kerjasama Luar Negeri contract number 1012/UN35.13/LT/2021 and Penelitian Dasar contract number: 904/UN35.13/LT/2021.

\section{Authors' Note}

I, Rusnardi Rahmat, declares that there is no conflict of interest regarding the publication of this article. I confirm that the data and the paper are free of plagiarism.

\section{REFERENCES}

[1] D. H. Natawidjaja and W. Triyoso, "The Sumatran fault zone - From source to hazard," J. Earthq. Tsunami, 2007, doi: 10.1142/s1793431107000031.

[2] Putra, Rusnardi Rahmat., J. Kiyono, Y. Ono, and H. R. Parajuli, "Seismic hazard analysis for Indonesia," J. Nat. Disaster Sci., 2012, doi: 10.2328/jnds.33.59.

[3] E. Juliafad, H. Gokon., Putra, Rusnardi Rahmat., "DEFECT STUDY ON SINGLE STOREY REINFORCED CONCRETE BUILDING IN WEST SUMATRA : BEFORE AND AFTER 2009 WEST,” vol. 20, no. 77, pp. 205-212, 2021.

[4] A. Muhammad, K. Goda, and N. Alexander, "Tsunami hazard analysis of future megathrust sumatra earthquakes in Padang, Indonesia using stochastic tsunami simulation," Front. Built Environ., 2016, doi: 10.3389/fbuil.2016.00033.

[5] A. Muhammad, K. Goda, N. A. Alexander, W. Kongko, and A. Muhari, "Tsunami evacuation plans for future megathrust earthquakes in Padang, Indonesia, considering stochastic 
earthquake scenarios,” Nat. Hazards Earth Syst. Sci., 2017, doi: 10.5194/nhess-17-2245-2017.

[6] F. Imamura, A. Muhari, E. Mas, M. H. Pradono, J. Post, and M. Sugimoto, "Tsunami disaster mitigation by integrating comprehensive countermeasures in Padang city, Indonesia," J. Disaster Res., 2012, doi: 10.20965/jdr.2012.p0048.

[7] F. Ai, L. K. Comfort, Y. Dong, and T. Znati, "A dynamic decision support system based on geographical information and mobile social networks: A model for tsunami risk mitigation in Padang, Indonesia," Saf. Sci., 2016, doi: 10.1016/j.ssci.2015.09.022.

[8] S. Brune, A. Y. Babeyko, C. Gaedicke, and S. Ladage, "Hazard assessment of underwater landslide-generated tsunamis: A case study in the Padang region, Indonesia," Nat. Hazards, 2010, doi: 10.1007/s1 1069-009-9424-x.

[9] Putra, Rusnardi Rahmat., J. Kiyono, and A. Furukawa, "Vulnerability assessment of non engineered houses based on damage data of the 2009 padang earthquake in Padang city, Indonesia," Int. J. Geomate, 2014, doi: 10.21660/2014.14.140714.

[10] P. S. Thein, Pramumijoyo Subagyo Brotopuspito, Kirbani Sri Wilopo, Wahyu,Kiyono Junji, Setianto Agung, Putra, Rusnardi Rahmat., "Designed microtremor array based actual measurement and analysis of strong ground motion at Palu city, Indonesia,” 2015, doi: 10.1063/1.4915040.

[11]L. K. Katherina, "Dinamika Pertumbuhan Penduduk Kota-Kota di Indonesia," Lemb. Ilmu Pengetah. Indones., 2018.

[12] Putra, Rusnardi Rahmat., "Estimation of VS30 based on soil investigation by using microtremor observation in padang, Indonesia,” Int. J. G, 2017, doi: 10.21660/2017.38.tvet030.

[13] M. H. Pradono, "Kajian Kerentanan Gempabumi Gedung Bertingkat Dengan Bentuk Beaturan Dan Tidak Beraturan," J. Sains dan Teknol. Indones., 2019, doi: 10.29122/jsti.v16i3.3416.

[14] A. Kirke and H. Hao, "Estimation of failure probabilities of RC frame structures in Singapore to the simulated largest credible ground motion," Eng. Struct., 2004, doi: 10.1016/j.engstruct.2003.09.007.

[15]E. Rita, R. Permata, H. Yonne, and N. Carlo, "Tsunami shelter in Padang city: Location suitability and management issue," 2017, doi: 10.1063/1.5011629.

[16] J. Faure Walker and C. Anna Crawford, "Cash in a housing context: Transitional shelter and recovery in Japan," Int. J. Disaster Risk Reduct., 2017, doi: 10.1016/j.ijdrr.2017.05.01 8.

[17] Putra, Rusnardi Rahmat., "Damage investigation and re-analysis of damaged building affected by the ground motion of the 2009 Padang earthquake," Int. J. Geomate, 2020, doi: 10.21660/2020.66.Icee2nd.

[18] Putra, Rusnardi Rahmat., "Estimation of earthquake ground motion in Padang, Indonesia," Int. J. Geomate, 2011, doi: 10.21660/2011.1p
[19] Y. Ono, T. Noguchi, Putra, Rusnardi Rahmat., S. Uemura, T. Ikeda, and J. Kiyono, "Estimating subsurface shear wave velocity structure and site amplificating characteristics of Padang, Indonesia," J. Japan Soc. Civ. Eng. Ser. A1 (Structural Eng. Earthq. Eng., 2012, doi: 10.2208/jscejseee.68.i 227.

[20] Putra, Rusnardi Rahmat., J. Kiyono, Sai K. Vanapalli, Y. Ono" Relationship between Shear Velocities Recorded by Microtremor Observations and Seismic Cone Penetration Test Results. Indonesian Journal of Science \& Technology 6 (2) (2021) 315-336.

[21]H. F. Estrella and J. A. González, "SPAC: An alternative method to estimate earthquake site effects in Mexico City," Geofis. Int., 2003, doi: 10.22201/igeof.00167169p.2003.42. 2.267 .

[22] Y. Zhang, S. Wang, and G. Ji, "A comprehensive survey on particle swarm optimisation algorithm and its applications," Mathematical Problems in Engineering. 2015, doi: $10.1155 / 2015 / 931256$.

[23] The Japan Building disaster Prevention Association. Seismic Evaluation and retrofit, 2001.

[24] S. Gayen, I. V. Villalta, and S. K. M. Haque, "Earthquake hazard scenario and seismic micro-zoning assesment in Málaga province of Spain,” Eur. J. Geogr., vol. 10, no. 1, 2019.

[25] R. Govers, K. P. Furlong, L. van de Wiel, M. W. Herman, and T. Broerse, "The geodetic signature of the earthquake cycle at subduction zones: Model constraints on the deep processes," Rev. Geophys., vol. 56, no. 1, 2018, doi: 10.1002/2017RG000586.

[26] A. M. Sari and A. Fakhrurrozi, "Earthquake Hazard Analysis Methods: A Review," in IOP Conference Series: Earth and Environmental Science, 2018, vol. 118, no. 1, doi: 10.1088/1755-1315/118/1/012044.

[27] Kurniawandy, A. and Nakazawa, S. (2019) 'Seismic performance evaluation of existing building using Seismic Index method', MATEC Web of Conferences, 276, p.01015.doi: 10.1051/matecconf/201927601015.

[28] Sutrisno, Putra, Rusnardi Rahmat, and Ganefri (2017). A comparative study on structure in building using different partition receiving expense Earthquake. International Journal of GEOMATE. doi: 10.21660/2017.37.TVET019.

[29] Reza Latifi , Rahimeh Rouhi , "Seismic Assessment and Retrofitting of Existing RC Structures: SeismoStruct and SeismoBuild Implementation," Civil Engineering and Architecture, Vol. 8, No. 2, pp. 84 - 93, 2020. DOI: 10.13189/cea.2020.080206.

[30] Poleswara Rao Kovela, Balaji K. V. G. D, Phanindranath T. S. D , B. Santhosh Kumar , "Effect of Additional Reinforcement Length in Beams on Base-Shear Capacity in Performance-based Design of Low-Rise Buildings," Civil Engineering and Architecture, Vol. 9, No. 1, pp. 9 - 22, 2021. DOI: 10.13189/cea.2021.090102. 